\title{
Shrinkage Behavior of Peat - Polymer Mixtures
}

\author{
Siti Nooraiin Mohd Razali, Adnan Zainorabidin, Ismail Bakar, Nursyahidah Saedon, Mohamad Niizar \\ Abdurahman, Mardiha Mokhtar
}

\begin{abstract}
Peat soil is a challenging soil with brownish-black in color, consist of high decomposed organic material, high moisture content (>100\%), high compressibility (0.9-1.5), low shear strength (5-20 $\mathrm{kPa}$ ) and high organic matter (>75\%). Peat with high moisture experienced it's highest decreased of moisture when dried. With the larger shrinkage capacity, the fibrous peat are able to reduce the volume up to $50 \%$ following air drying. The objective of this study is to identify the shrinkage behavior of original peat and stabilized peat by using Vinyl Acetate - Acrylic Copolymer (VAAC). In this study, a laboratory investigation was conducted by using bar linear shrinkage and cylindrical sample measurement. This polymer can be used to increase the strength of soil and also able to fill the pore medium thus create water proof surface upon drying. Hence the moisture loss can be control and the shrinkage can be reduced. Results show that the value of original peat shrinkage is $26.17 \%$ and $28 \%$ for bar linear shrinkage method and cylindrical sample measurement method respectively. After added VAAC mixtures, the shrinkage reduce up to $9 \%$ and $12 \%$ for both method. Hence, this VAAC polymer can be concluded as a good agent to control the shrinkage problems.
\end{abstract}

\section{Index terms: Shrinkage, peat, stabilized, polymer}

\section{INTRODUCTION}

Soil that contained more than $75 \%$ of organic matter was considered as peat soil. It is formed under conditions of water saturation, acidity, nutrient deficiency and low oxygen availability while the rate of organic matter accumulates more quickly than the rates of humidified [1]. Peat soil is a challenging soil with brownish-black in color and consist of high decomposed organic material. The increased of decomposed organic material will increased the fiber content in peat. Hence, its indicates the increment of the small pores or void ratio between the fiber particles [2]. Thus, it tends to give high porosity (exceed 80\%) and shrinkage. This soil also consist of high porous media with special behavior such as high moisture content (>100\%), high compressibility (0.9-1.5), low shear strength (5-20 kPa) and high organic matter (>75\%) as stated by [3].

Revised Manuscript Received on June 22, 2019.

Siti Nooraiin Mohd Razali, Centre for Diploma Studies, Universiti Tun Hussein Onn Malaysia, Hab Pendidikan Tinggi Pagoh, KM1, Jalan Panchor, 84600 Pagoh, Muar, Johor.

Adnan Zainorabidin, Faculty of Civil and Environmental Engineering, Universiti Tun Hussein Onn Malaysia, Parit Raja, 84600 Batu Pahat, Johor.

Ismail Bakar, Faculty of Civil and Environmental Engineering, Universiti Tun Hussein Onn Malaysia, Parit Raja, 84600 Batu Pahat, Johor.

Nursyahidah Saedon, Faculty of Civil and Environmental Engineering, Universiti Tun Hussein Onn Malaysia, Parit Raja, 84600 Batu Pahat, Johor.

Mohamad Niizar Abdurahman, Faculty of Civil and Environmental Engineering, Universiti Tun Hussein Onn Malaysia, Parit Raja, 84600 Batu Pahat, Johor.

Mardiha Mokhtar, Centre for Diploma Studies, Universiti Tun Hussein Onn Malaysia, Hab Pendidikan Tinggi Pagoh, KM1, Jalan Panchor, 84600 Pagoh, Muar, Johor.
These characteristic also made the peat pose its own distinctive geotechnical properties compared with other inorganic soils which are made up by the soil particle only [4]. The pore structure in peat presence in three types which are open and connected, dead - ended or isolated [5].

The volume change normally related with the shrinkage or swelling occurred in soil. As stated by [6], volume changes in peat because of normal compression and this volume changes is equal to the volume of water lost in soil pores. Residual shrinkage tends to change the volume when air enters the soil are significantly smaller than for normal shrinkage. Therefore, water gained or lost by volume changes of peat need to be considered when evaluating water storage changes.

Inadequate strength is one of important causes of the column failure. This failure often occurred because of the organic matter in peat which is impeded the cementing process thus reduced the strength gained in peat. Many researchers study the strength changes instead of shrinkage behavior.

It's also important to observe the shrinkage behavior in original and stabilized peat. Hence, in this study, a laboratory investigation was conducted by using bar linear shrinkage and cylindrical sample measurement for original and stabilized peat by using Vinyl Acetate - Acrylic Copolymer (VAAC). This polymer can be used to increase the strength of soil, control the dust and also reduce the erosion. The objective of this study is to identify the shrinkage behavior of original peat and stabilized peat.

\section{LITERATURE REVIEW}

The weight and volume of peat tends to decrease upon drying and this process usually termed as shrinkage. The shrinkage of peat soil normally accompanied with the moisture changes has strong influence on the physical attributes and soil water management. Several forces acting on a micro-scale and change the mechanism and magnitude in organic due to shrinkage or swelling [7]. The rate of peat shrinkage is influenced by the type of peat, rate of decomposition, bulk density and ash content (as cited by [8]).

Peat had high soil moisture, but experienced its highest decreased of moisture when dried and oxidation of peat results in a permanent changes to peat material. This peat also unable to return to its original water content [9].With the larger shrinkage capacity, the fibrous peat are able to reduce the volume up to $50 \%$ following air drying [10]. Peat will not swell up upon re-saturation because dried peat only can re-absorb only $33 \%$ to $55 \%$ of water [11]. Plant structure have a tendency to shrink more across the fiber 
widths instead of the length and its plant fiber are naturally horizontal aligned in situ which make the shrinkage in vertical and horizontal different [12]. The water holding capacity and particle porosity of peat reduce when the thinwalled tissues shrink and the cellular structure collapse [13].

Paivanen [14] discussed the amount of shrinkage in volumetric undisturbed peat sample in $105^{\circ} \mathrm{C}$ oven-dried condition. It was concluded that the amount of shrinkage is related to various physical properties of peat. It also highlighted that there were two phases occur in the drying process which were structural water loss phase and shrinkage water loss phase. During the structural water loss phase there is no shrinkage occurred but in the shrinkage water loss phase there are linear relationship between the water and volume loss. Oleszczuk [7] have discovered that the load applied strongly effects the relationship between shrinkage geometry factor and moisture ratio. Results show the higher values of subsidence and lower values of crack volume by compared it with unloaded soil condition. Oleszczuk [8] also investigated the soil volume changes for moorsh, willow and moss peat layers during drying-wetting cycles. By using the 'saran resin' method, the reversible and irreversible shrinkage coefficient values were calculated. Hamamoto[15] study an advance in peat shrinkage which is related to the heat transport of peat soil at variably saturated conditions and effect of volume shrinkage on thermal properties of peat soil. Zainorabidin [16] investigated the soil volume changes and the shrinkage at four dimensional points and bar linear shrinkage method. Table 1 shows linear shrinkage value that have been conducted forpeat soil in Malaysia.

Table. 1 Shrinkage value of peat in Malaysia

\begin{tabular}{lcc}
\hline \multicolumn{1}{c}{ Location } & Shrinkage (\%) & Reference \\
\hline Rengit, Johor & 35.24 & {$[17]$} \\
Matang, Sarawak & 5.35 & {$[18]$} \\
Parit Nipah, Johor & 34.77 & {$[16]$} \\
Pontian, Johor & 33.09 & {$[16]$} \\
\hline
\end{tabular}

The linear shrinkage can be calculated by using the equation:

$$
\mathrm{LS}=\left(1-\mathrm{L}_{\mathrm{avg}} / \mathrm{L}_{0}\right) \times 100
$$

Where:

LS = Linear Shrinkage (\%)

$\mathrm{L}_{\mathrm{avg}}=$ Average Length (mm)

Lo $=$ Original Length of Brass Mold (mm)

\section{MATERIAL AND METHOD}

\section{Peat Sampling}

The disturbed sample was excavated in Parit Nipah, Batu Pahat, Johor. To avoid any disruption of sample form visible root and branches, the top soil were removed before conduction the sampling process. The surrounding location is mostly planted with pineapple and palm tree. Ground water table was found to be about $0.5 \mathrm{~m}$ from the ground surface. Visual inspection of peat soil were indicating that it has a very high water retention capacity, dark brown in colour and it also very spongy when step in their surface. A Von post classification test was conducted to identify its class by squeezing the peat soil. It releases very muddy dark water with a small amount of peat passed through the fingers and really sticky. Hence, this Parit Nipah peat soil can be classified as H5. In order to maintain its properties and moisture content, the disturbed samples were kept in a controlled humid room that available at lab. This controlled room used to avoid any fungus grows on the surface of the soil since peat soil itself is formed by decayed of wood and root. All the tests were conducted in Research Centre for Soft Soil (RECESS), UTHM, Johor.

\section{Basic Properties}

For basic properties identification, these sample were prepared by following the method that provided in British Standard and ASTM. Results of this study is as shown in Table 2 .

Table. 2 Properties of Peat Soil in Malaysia

\begin{tabular}{|c|c|c|c|c|c|c|c|}
\hline \multirow{2}{*}{$\begin{array}{c}\text { Properties } \\
\text { Moisture Content (\%) }\end{array}$} & \multirow{2}{*}{$\begin{array}{c}\begin{array}{c}\text { West } \\
\text { Malaysia }\end{array} \\
200-700 \\
\end{array}$} & \multirow{2}{*}{$\begin{array}{c}\begin{array}{c}\text { East } \\
\text { Malaysia }\end{array} \\
200-2207 \\
\end{array}$} & \multicolumn{2}{|c|}{ Pontian, Johor } & \multicolumn{3}{|c|}{ Parit Nipah author } \\
\hline & & & 460 & 765.2 & 791 & 701 & 605 \\
\hline Liquid Limit (\%) & $190-360$ & $210-550$ & 224 & 230 & 119 & 335.2 & 203.5 \\
\hline Specific Gravity & $1.38-1.7$ & $1.7-1.63$ & 1.38 & 1.6 & 1.88 & 1.43 & 1.4 \\
\hline Unit Weight (kN/m3) & $8.3-11.5$ & $8-12$ & $7.5-102$ & 12.74 & - & - & 11.47 \\
\hline $\begin{array}{l}\text { Undrained Shear Strength } \\
(\mathrm{kPa})\end{array}$ & 17.8 & $8-10$ & 11.7 & - & - & - & - \\
\hline $\mathrm{pH}$ & - & - & 3.1 & 3.42 & 3.6 & 3.69 & 3.75 \\
\hline Fibre Content (\%) & - & - & 62 & - & 18 & 40.97 & 56 \\
\hline Von Post Humification & - & - & H5 & H5 & $\mathrm{H} 4$ & H5 & H5 \\
\hline
\end{tabular}

The existence of organic matter in peat generally associated with low strength characteristic and high compressibility; thus often increase the settlement and foundation failure. The construction of structures and road become difficult with the presence of organic. 
Because of these unique properties; high compressibility, low strength, volume instability and high settlement, peat always regarded as the worst foundation soil to support man-made structures. The behavior of peat does not follow the traditional rules of soil behavior, thus need a special design while dealing with this soil. As in Figure 1 (a), the settlement of peat is directly below the footing and the vertical shearing of soil under the soil perimeter. The stress induced outside the loaded area remain uninvolved but just only a small movement of soil observed on both sides of footing [23]. Hence, the punching shear failure occurred in peat. By compared it with the sand loaded with the same value of pressure, the general failure pattern appeared and it can be seen that the rupture and push up sand on both sides of footing (Figure 1 (b)).

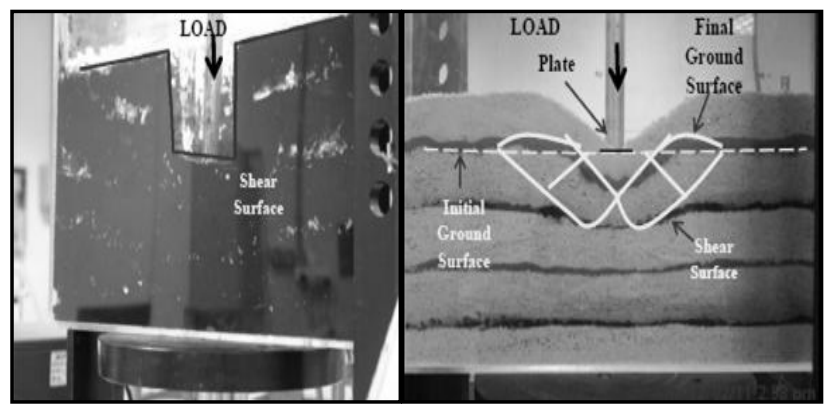

Fig. 1 Failure in soil (a) peat and (b) sand [23]

\section{Sample Preparation}

Two types of shrinkage observation were made by following the standard laboratory method (Bar Linear Shrinkage) and by the measurement of the cylindrical sample size changes. The original and stabilized peat soil was placed in the bar mould for the shrinkage measurement. The results obtained were compared for both conditions. The other method is by measured the diameter (at the top, centre and bottom) and length of the original and stabilized cylindrical. All the measurement were conducted by using Vernier Calliper and weighing scale. The results obtained were compared with the previous method. The discussions were made based on these methods.

\section{Shrinkage Test}

This test was conducted by following British Standard. The peat sample with size passing $425 \mu \mathrm{m}$ wet sieving were used. The shrinkage bar was filled with peat sample and placed in open aired until a gap between peat and bar appeared. Then, proceed with next step by placed the sample in the oven at temperature $60^{\circ} \mathrm{C}$ (below $65^{\circ} \mathrm{C}$ ) until shrinkage has largely ceased. The last step is by oven-dried this sample at $105{ }^{\circ} \mathrm{C}$ to complete the drying process. Measure the average shrinkage of the sample at three different point as in Figure 2.

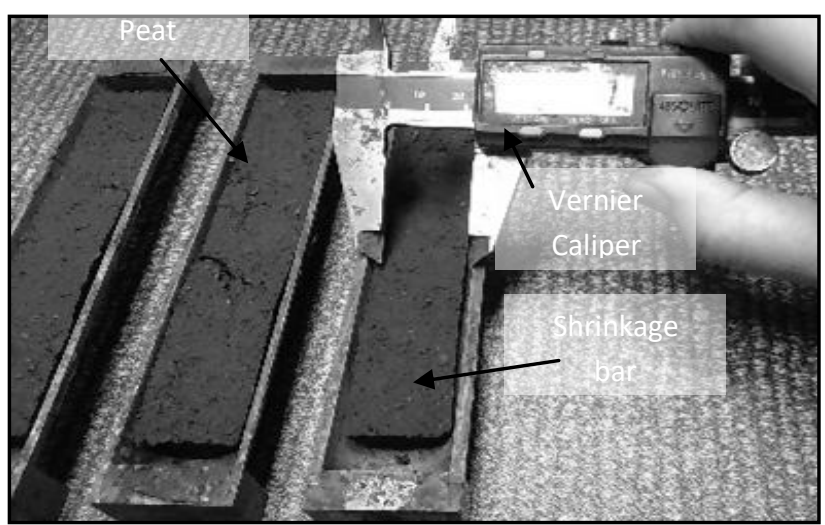

Fig. 2 Bar linear shrinkage

\section{Cylindrical Sample Measurement}

This measurement were made to observe the uniformity of shrinkage in the cylindrical sample. This method considered as modification method since the linear shrinkage value of peat can be determined in various method [16]. By using a mould with size $50 \mathrm{~mm}$ in diameter and $100 \mathrm{~mm}$ in height, the sample for this method was formed. The original peat were placed in the mould and tamped it for three layers. Daily observation (shrinkage measurement) were made for 14 days at normal room temperature compatible with the curing method for strength identification as shown in Fig. 2. This steps then repeated for stabilization peat with $10 \%$, $30 \%, 50 \%$ and $70 \%$ of VAAC. The measurement point is as shown in Figure 3. The diameter of the sample were taken at three differences points which is center, $40 \mathrm{~mm}$ from center to the top and $40 \mathrm{~mm}$ from center to the bottom. The shrinkage in length of the sample were also recorded.

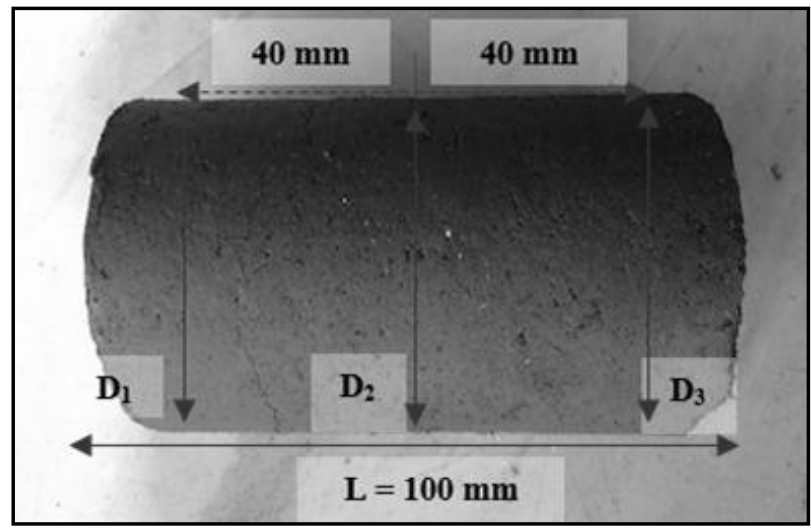

Fig. 3 Measurement point

\section{RESULTS AND DISCUSSIONS}

The shrinkage result from bar linear shrinkage method for the original sample and stabilized sample is as shown in Table 3. The original sample is shrink up to $26 \%$ and this values tends to decrease with the increasing of percentage of mixtures. But at $10 \%$ of mixture, the shrinkage higher than the original sample because of the polymer did not start react with the peat. As in the result obtained, this VAAC started to act and bind with the soil particles at $30 \%$ of mixture.

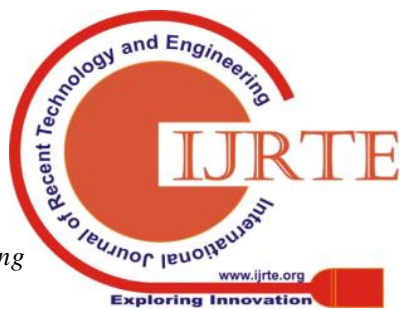


Table. 3 Shrinkage result

\begin{tabular}{ll}
\hline Sample & Shrinkage Value \\
\hline Original & 26.17 \\
$10 \%$ & 27.12 \\
$30 \%$ & 20.2 \\
$50 \%$ & 17.27 \\
$70 \%$ & 16.41 \\
\hline
\end{tabular}

\section{Shrinkage in Diameter}

Figure 4 shows the shrinkage (in diameter) at point $\mathrm{D}_{1}, \mathrm{D}_{2}$ and $\mathrm{D}_{3}$ for different percentage of mixtures. For the original sample ( $0 \%$ VAAC), the shrinkage value for these three point was scattered and varied. But with the increasing of the percentages of VAAC the shrinkage gradually become uniform for top, middle and bottom of the sample.

The maximum shrinkage value for original sample is more than $30 \%$. With the existence of the VAAC, the percentage of shrinkage tends to decreased as for the $70 \%$ of VAAC, the shrinkage reduce to $20.5 \%$. The shrinkage test were proceed until reach their constant value. The result shows that for original and $10 \%$ of VAAC its took about 16 days to reach its constant value and for $35 \%, 50 \%$ and $70 \%$ mixture of VAAC, the time taken to constant is 18 days. But this paper only focus up to 14 days related to the strength optimum achieved from the unconfined compression test result.

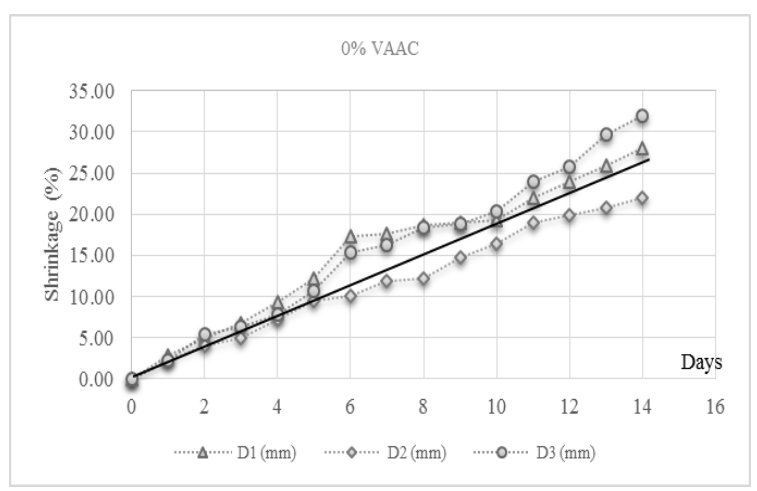

(a)

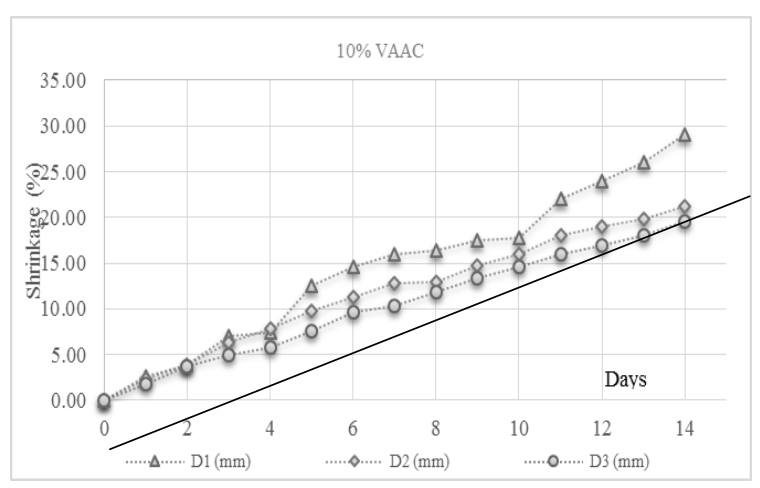

(b)

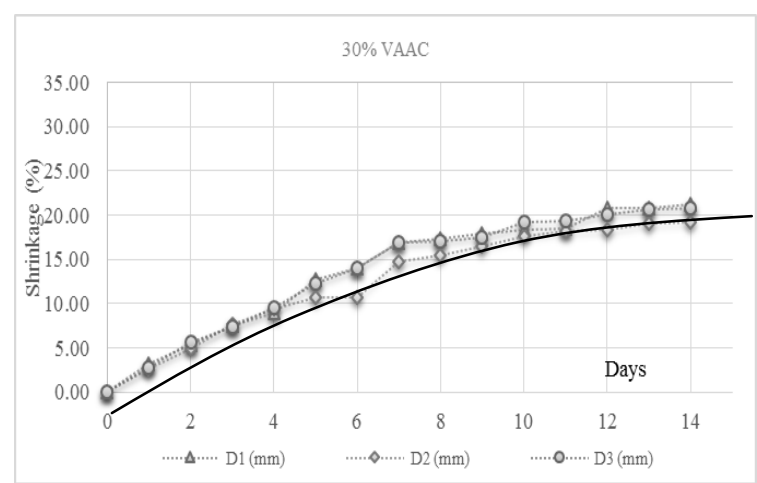

(c)

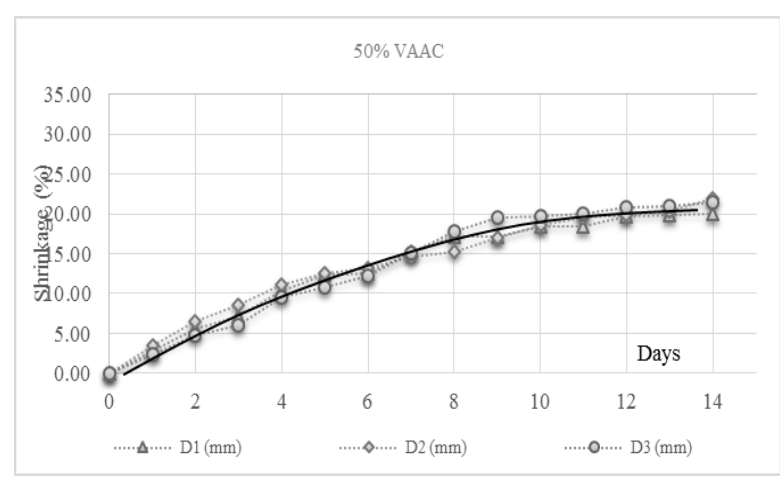

(d)

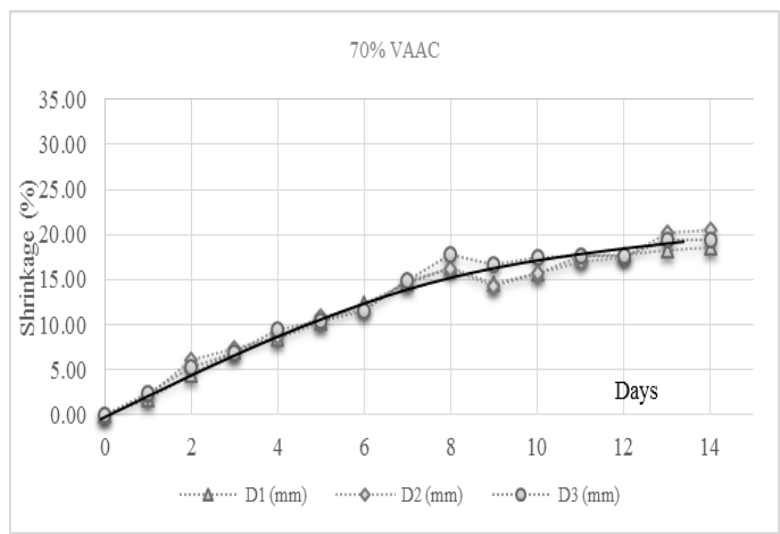

(e)

Fig. 4 Shrinkage at different mix percentages (a) original peat, (b) peat $+10 \% \mathrm{VAAC}$, (c) peat $+30 \% \mathrm{VAAC}$, (d) peat $+50 \%$ VAAC and (e) peat $+70 \%$ VAAC.

Figure 5 shows the influence of difference mixtures of VAAC to shrinkage at the same day; for example day 1, day 7 and day 14. Based on the observation, these results can be divided into three stage which is initial, intermediate and constant stage. The increasing percentage of peat affecting the trendline of the shrinkage. During the initial stage, the increasing of VAAC lead to decrease the shrinkage value. But in intermediate stage it was separated into 2 parts which were increased in trendline started from day 1 to day 10, and decreased after that until it's reach it constant stage. At constant stage, which is from $30 \%$ of VAAC to $70 \%$ VAAC the shrinkage tends to constant. 


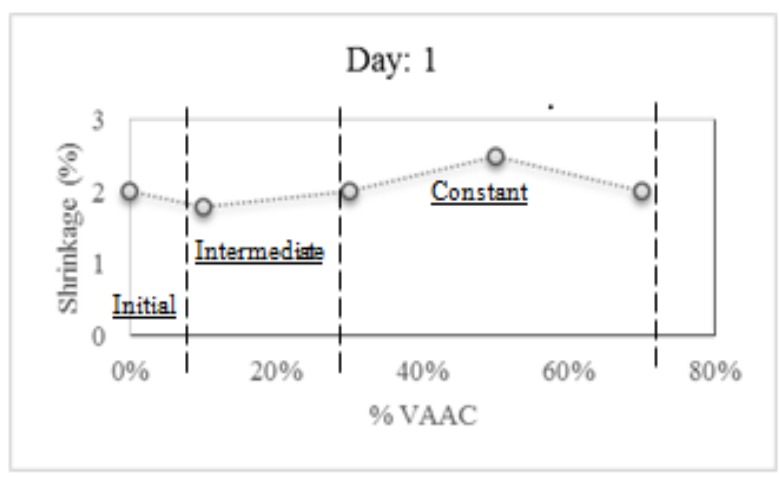

(a)

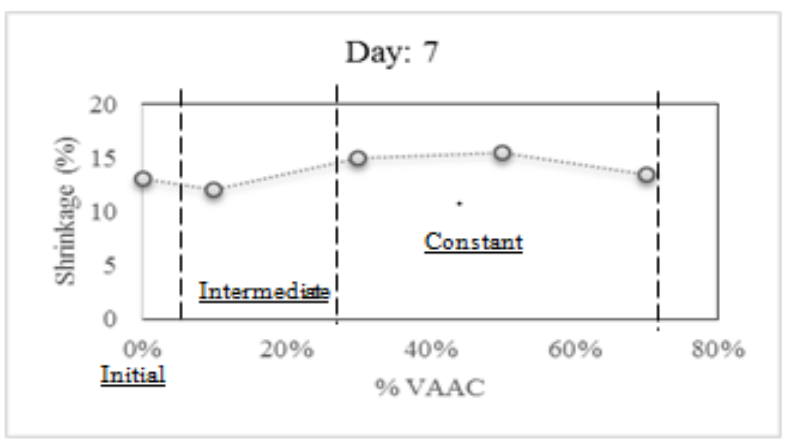

(b)

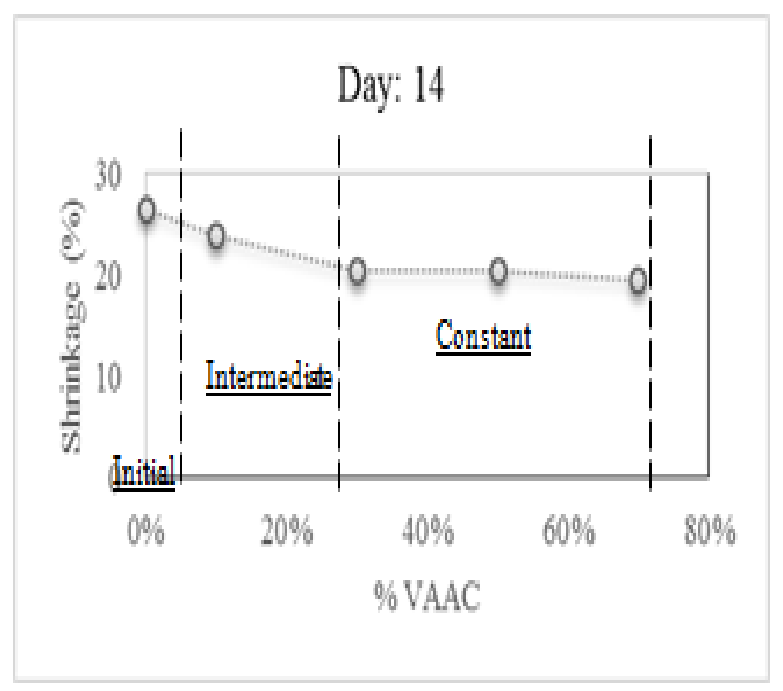

(c)

Fig. 5 Influence of different mixture at the same day (a) day 1, (b) day 7 and (c) day 14

\section{Shrinkage in Length}

Figure 6 shows the shrinkage in length for original and stabilized sample. Results show that the percentage of length shrinkage was higher for original peat and peat with $10 \%$ of VAAC. But with the increasing of VAAC, the shrinkage was decreased. From this output, it can be concluded that the polymer started to react at $30 \%$ until $70 \%$.

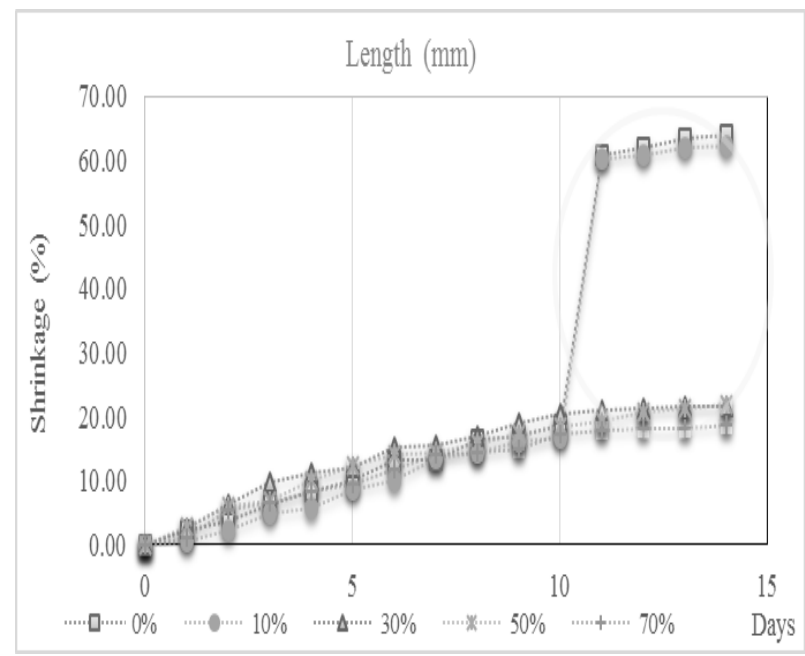

Fig. 6 Shrinkage in length

\section{Shrinkage in Volume}

Figure 7 shows the percentage of volume shrinkage in original and stabilized peat. It shows that the shrinkage was higher for original peat and $10 \%$ of VAAC stabilize peat. The percentage decreased with the increasing of VAAC. During day 0 to day 14 , there are general increasing of volume shrinkage in peat. But for original peat and peat with $10 \%$ VAAC, the peat dried rapidly after day 11 to day 14 . The diameter and length of the sample is directly proportional to the volume of the peat sample. The decrease in diameter and length will decreased the peat volume.

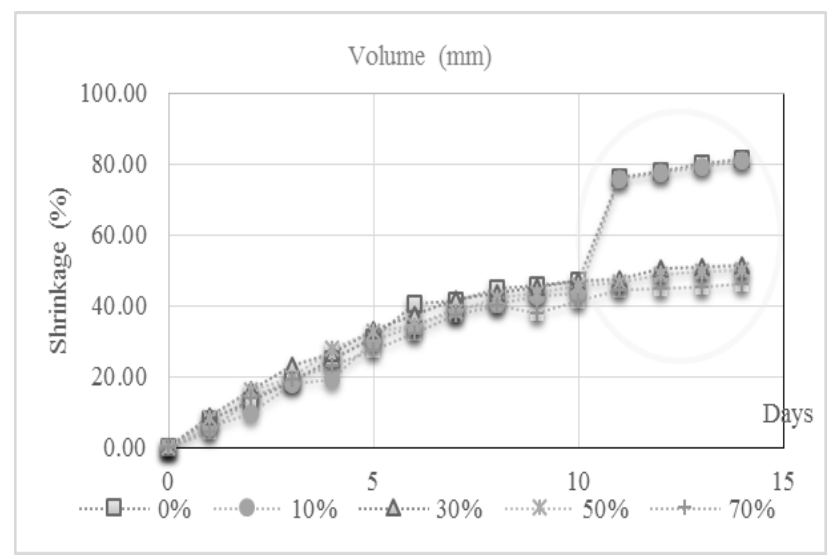

Fig. 7 Shrinkage in volume

Peat consist of large pores that are highly irregular and interconnected. This weak soil comprise two porous medium which is 'mobile region' and 'immobile region'. In mobile region, water, solute and colloids are able to through easily. However, for immobile region, the fluid flow velocity can be neglected [5]. The cellular structure fiber in peat consist of two level structure involving macro (between fibers) and micro (within fibers) pores. The fibers in peat consist of cellular structure involving micro and macro pores which is those between the fiber and within the fiber [19]. Hence, because of the mobility process and large pore in peat, the polymer are able to replace the water in porous medium. 
This VAAC itself have a special behavior which is it can form a water proof surface upon drying. The ability of this VAAC to fill the pore medium helped to reduce the loss of moisture and reduced the shrinkage. Since the sample were cured at the same room temperature, the effect of temperature increase can be controlled.

\section{CONCLUSION}

In this study, the value of original peat shrinkage is $26.17 \%$ and $28 \%$ for bar linear shrinkage method and cylindrical sample measurement method respectively. It is in the range of the shrinkage value for West Malaysia which is 20 to $40 \%$ as reported by [25]. After added VAAC mixtures, the shrinkage reduce up to $9 \%$ and $12 \%$ for both method. Hence, this VAAC polymer can be concluded as a good agent to control the shrinkage problems.

\section{ACKNOWLEDGMENT}

The authors wish to express their gratitude to all members who helped and give a big support in this study. The research work reported in funded by TIER GRANT(U920),RMC, University Tun Hussein Onn Malaysia (UTHM). The authors wish to express their gratitude to RECESS - UTHM and Geotechnics Engineering Laboratory, FKAAS - UTHM in providing the equipment during carrying out this research.

\section{REFERENCES}

1. Kleimeier, C, F Rezanezhad, P Van Cappellen, and B Lennartz. 2017 "Influence of Pore Structure on Solute Transport in Degraded and Undegraded Fen Peat Soils." International Mire COnservation Group and International Peatand Society 19(October): 1-9. 1. Boelter, D.H. 1968. "Important Physical Properties of Peat Materials." In Third International Peat Congress, Quebec, Canada, , 150-54.

2. Razali, Siti Nooraiin Mohd, Ismail Bakar, and Adnan Zainorabidin. 2013. "Behaviour of Peat Soil in Instrumented Physical Model Studies." Procedia Engineering 53: 145-55. http://dx.doi.org/10.1016/j.proeng.2013.02.020.

3. Deboucha, S., Hashim, R., and Alwi, A. 2008. "Engineering Properties of Stabilized Tropical Peat Soils." EJGE 13.

4. Rezanezhad, Fereidoun et al. 2016. "Structure of Peat Soils and Implications for Water Storage, Flow and Solute Transport: A Review Update for Geochemists.” Chemical Geology 429: 75-84. http://dx.doi.org/10.1016/j.chemgeo.2016.03.010.

5. Price, Jonathan S., and Susanne M. Schlotzhauer. 1999. "Importance of Shrinkage and Compression in Determining Water Storage Changes in Peat: The Case of a Mined Peatland." Hydrological Processes 13(16 SPEC. ISS.): 2591-2601.

6. Oleszczuk, Ryszard et al. 2003. "Influence of Load on Shrinkage Behavior of Peat Soils.” Journal plant nutr. soil sci. c(166): 220-24.

7. Oleszczuk, R, and T Brandyk. 2008. "The Analysis of ShrinkageSwelling Behaviour of Peat-Moorsh Soil Aggregates during DryingWetting Cycles." 6(1): 131-40.

8. Timoney, M.J., McCabe, B.A., and Bell, A.L. 2012. "Experiences of Dry Soil Mixing in Highly Organic Soils.” Proceedings of ICE Ground Improvements 165 (GII): 3-14.

9. Kazemian, Sina, Bujang B K Huat, Arun Prasad, and Maassoumeh Barghchi. 2011. "A State of Art Review of Peat: Geotechnical Engineering Perspective.” 6(8): 1974-81.

10. Yulindasari. 2006. "Compressibility Characteristics of Fibrous Peat Soil.” Msc Thesis, UTM (October).

11. Raghunandan, Mavinakere Eshwaraiah, and Anirudh Subramanya Sriraam. 2017. "An Overview of the Basic Engineering Properties of Malaysian Peats.” Geoderma Regional 11(August): 1-7. https://doi.org/10.1016/j.geodrs.2017.08.003.

12. Wong, L. S, Hashim, R. and Ali, F.H. 2009. "A Review on Hydraulic Conductivity and Compressibility of Peat.” (June).
13. Paivanen, Juhani. 1982. "Physical Properties of Peat Samples in Relation to Shrinkage Upon Drying.pdf." Silva Fennica 16(3): 247-65.

14. Hamamoto, S, S Dissanayaka, K Kawamoto, and T Komatsu. 2010. "Effects of Moisture Content and Shrinkage on Soil-Thermal Properties for Peat Soils in Japan.” (December): 13-14.

15. Zainorabidin, Adnan, Nursyahidah Saedon, Ismail Bakar, and Nurul Farhana. 2014. "An Investigation of Soil Volume Changes at Four Dimensional Points of Peat Soil Sample in Parit Nipah and Pontian.” In Tropical Soil International Conference on International Integrated Engineering Summit (IIES) 2014, , 2-7.

16. Mohyeddin, M.N., Zainorabidin, A., Madun, A., Yusof, M.F., Mokhtar, M. and Chew, Y.F. 2007. "Some Index Properties on Rengit Peat Soil Stabilize With Cement-Lime Prosiding Kebangsaan Awam 07 ,.” In Prosiding Kebangsaan Awam 07, Langkawi, Kedah, , 29-31.

17. Kolay, P.K., Sii, H. Y., and Taib, S.N.L. 2011. "Tropical Peat Soil Stabilization Using Class F Pond Ash from Coal Fired Power Plant." International Journal of Civil and ENvironmental ENgineering (3:2): 79-83.

18. Huat, B. B.K. (2004). Organic and Peat Soils Engineering. Universiti Putra Malaysia Press, Serdang, Malaysia, pp. 20-80.

19. Zainorabidin, A., and Bakar I., (2003). Engineering Properties of insitu and Modified Hemic Peat Soil in Western Johore.

20. In Proceedings of 2nd International Conference on Advances in Soft Soil Engineering and Technology (pp. 252 - 261). Putra Jaya, Malaysia.

21. Atemin, H. H. (2013). A Study on Consolidation and Permeability Properties of Tropical Peat. Master Thesis. UTHM.

22. Saedon, N(2016). Comparative Study of the Shrinkage Characteristics of Peat at South East Johore. Master Thesis. UTHM.

23. Razali, Siti NooraiinMohd (2013) Instrumented physical model studies of the peat soil engineering structure interaction. Masters thesis, Universiti Tun Hussein Onn Malaysia.

24. Zainorabidin, A., (2010). Static and Dynamic Characteristics of Peat with Macro and Micro Structure Perspective. PhD Thesis. UEL.

25. Hashim, R., and Islam, S. 2008. "Engineering Properties of Peat Soil in Peninsular, Malaysia.” Journal of Applied Sciences 8 (22): 4215-19. 